\begin{tabular}{cc}
\hline Mournals & $\begin{array}{c}\text { INDUSTRIAL } \\
\text { MANETING AND BRANDING } \\
\text { RESEARCH }\end{array}$ \\
\hline
\end{tabular}

\title{
Trends and applications in city branding: A case study in Izmir
}

\author{
Ige Pirnar ${ }^{1}$, Metehan Igneci ${ }^{2}$, Melih Tutuncuoglu ${ }^{3 *}$ \\ ${ }^{1,2}$ Faculty of Economics and Administrative Sciences, Business Administration Department, Yasar University, \\ Izmir, Turkey \\ ${ }^{3}$ Faculty of Economics and Administrative Sciences, International Trade and Finance Department, Yasar \\ University, Izmir, Turkey
}

\begin{abstract}
Keywords:

City Branding, Branding Trends, Global Cities, Izmir

Correspondence:

melih.tutuncuoglu@yasar.e du.tr

This study aimed at analyzing the trends and unique different applications of city branding, which is a very popular and updated topic in the field of city management nowadays. This research covered a literature review on the global trends in city branding, new application types, and a few examples of successful city branding experiences. The study concluded with a real life case study in the form of SWOT analysis on Izmir's city branding applications, efforts, and strategies.
\end{abstract}

According to the definition which was approved by American Marketing Association, a brand is a name, term, sign, symbol, design or the combination of all of them in order to define, describe and differentiate one product or service apart from other similar ones (Odabasi \& Oyman 2004). Brand is a concept that helps marketers to create and position his/her products or services which related to the proposed images through differentiating outputs and comparing them with their competitors through highlighting and positioning unique characteristics of the brand. On the other hand, brand also helps marketers to increase their products power, enhance the prestige, and build goodwill through giving an identity to specific product or service. A brand has various descriptions among the targeted costumers based on brand selection process, brand usage, and ease of consumption (Atesoglu, 2003; Cifci, \& Cop, 2007; Kirdar, 2003; Pirnar, 2014). These descriptions are brand quality, brand benefit, brand personality or identity, brand culture, brand users or loyal groups, brand as a whole, and brand equity. Brand quality states that a brand should emphasize on distinguishing features of a product or service. A successful brand should initially represent its generated benefits through consuming of 
product or service. Brand personality or identity focuses on human set of characteristics associated with a brand with intangible attributes from customers' perspectives. Thus, a brand represents a promise to its customers to inspire them. A brand can also represent a culture, country, and region by highlighting the unique cultural elements residing within that location. Brand users or loyal groups state that a brand generates some opinions among different social classes and economical groups especially for those consumers who belong into the loyalty programs based on their status. Brand as a whole states that restricting a brand solely as a name or logo is a naive effort. A brand is not just a logo, picture, or a symbol. Apart from definition of a name or logo, it also reflects identity, personality, reputation, image, promise, price, added value, and advantageous elements of the products comparing the results of its competitors. In a nutshell, the competition among brands is based on the available differences that contribute to the uniqueness of certain product or service. Aaker (1996) highlighted the brand equity as added or omitted values and liabilities to products and services of an organization. Brand equity may be generalized as intangible assets which are valuable for products or services. Economic contribution provides a basis for this statement. Therefore, it seems that branding is one of the most important aspects of any business. Previous studies have demonstrated that brand equities of corporations have increased the market and stock values within the range of 5 to 20 per cent, which were divergent among the industries.

\section{City Branding and Characteristics}

City branding has become a valuable source for differentiating various cities around the world as the competition continues to grow among competitive regions. City branding can indeed be considered as a strategic tool which takes into account and promotes the economic, political, and cultural values in the cities and furthermore as a marketing tool which conveys the message focusing on the quality of place, history, lifestyle, standard of living, and culture as competitive advantage assets in cities (Oguztimur, \& Akturan, 2015). Thus, acquiring an identity for differentiating among cities aids destination and location marketing. After gaining an identity, cities may start to convey their messages to the society as a first step in the branding process. Revealing the tourism products of a city in the process of creating a brand requires involvement of public, private, and destination marketing organizations as well as citizens. Local principals should provide required contribution to the process of creating the brands while placing maximum emphasis on positive impacts of a city in creating a brand. Below specifications manifest the probability of success in the process of branding, if a city will plan to create a brand for a product (Chan, Peters, \& Marafa, 2015; Vanola, 2008). They are some important common elements for placing brand equity in city branding such as having cultural organizations like exhibit, arts, conferences, and concert organizations which are attractive for global environment, having an appropriate employment potential and attractive or entrepreneurial business opportunities, availability of advantageous prices and broad transportation infrastructure, availability of unique cultural heritage and similar sources, availability of natural resources, diversity in real estate investing, existence of global and attractive MICE activities and innovative activities, and familiarity, favorability, and uniqueness of tourist attractions.

\section{Characteristics of Successful City Brands}

Similar to destination marketing, successful brands in city branding possess certain similar but unique features; for instance, being different than others through highlighting this divergence, selecting a proper name for products, accurately implementing quality or prestige recalling, and positioning the precise qualifications are common features of successful city brands. Two topics are worthy of consideration with utmost importance with regard to city-brand management and brand strategies including infrastructure and quality. A brand that lacks of logistics or infrastructure most likely will 
not satisfy customers; therefore, they are destined to fail. Illustrations which are used in brands usually neglect these concepts and cannot response properly to available demands. If one presumes Istanbul as a case study, he/she should consider required number of hotels, tour operators, guidance services, transportation, package tours, points of tourist attraction, and any other tourism resources which are present within the city. Successful city branding should maintain consistency in terms of certain standards and qualities alongside with infrastructure. Accomplishment of a city brand is related directly to the quality obtained by the consumers and promises which are kept by the brands. Therefore, brand loyalty increases through reliability. The concept of branding a city generally differs when compared with a product's brand and its country; therefore, city tourism rise to prominence. Cities such as New York City, Paris, Amsterdam, London, Barcelona, and Istanbul have achieved these standards. They differ from their competitors due to their unique tourist destinations which promote them to an appropriate position. Referring to a research carried out by World Tourism Organization in terms of participating in the development of city tourism, 40 per cent of individuals within the age limit of 15-35 participate regularly on city tourism. This group mainly attracted by transportation, leisure, historical background, and culture. Second, demographic information of a group is within the range $35-55$ and 38 per cent of them participate regularly into city tourism while seeking branches of responsible tourism such as beaches, conventions, yacht tourism, gastronomy, eco-tourism, health tourism, and thermal tourism. The findings of this study showed that 20 per cent of the third group which its participants were over age 55, participate regularly in city-tourism and they are attracted mainly by health and culture tourism. City branding focuses over a singular direction within the globalization process of ideas, cultures, and reputations as well as phenomena (Hanna, \& Rowley, 2008). Even though the cities' branding efforts are global tendency, process may come in different shapes and structures; for instance, New York has been branded with the motto of second home of the world (Stigel \& Frimann, 2006). In successful city branding while harmonizing the image and identity of a brand, the brand promises that the companies commit to the people should be particularly appropriate for real product experience. Factors stated below are considered as the common success points of the branding processes in successful cities (Ashworth \& Kavaratzis, 2009; Järvisalo, 2012; Jin, Gubbi, Marusic, \& Palaniswami, 2014; Neirotti, et al., 2014; Ozdemir \& Karaca, 2009; Vanola, 2008; Zhang \& Zhao, 2009). These factors consist of branding in accordance with city's clarity; longevity, sustained attention, unforgettable experience, and professionalism of organization; richness in terms of ethnicities and diversity of cultures; qualified education opportunities for professionals and young students; existence of attractions, different leisure venues, and possibilities including night life; availability of high, popular, local, and cultural activities; stories unique to city herself; recommending brand positioning to citizens; internalizing brand image and identity by local government. There are also some other success factors of branding such as focusing on marketing, creating awareness, and customers' satisfaction on rural and urban branding together; adapting modern marketing approach and social marketing programs to city management; creating a network related to brand management and providing internal sustainability through constant monitoring of communication, perception alternations, and brand management processes; applications of key management principles of smart cities and using it in branding messages; following the smart city trends in brand management; adapting internet and IT (information technology) for enhancing the importance of services' delivery; compiling of network to open information sharing and discussing culture; emphasizing on unique and different city characteristics in positioning and branding; strategically determining the unique promotional characteristics of the related cities. 


\section{Contemporary Trends in City Branding}

Creating city brand is a new discipline that is used to build the structure of venues and develop cities by employing the obtained information through brands' communication strategies (Tek, 2009). At the end of their branding processes, cities are generally remembered with regard to the promises they gave and the unique features or stories they have (Järvisalo, 2012). While Paris reminds love and romance, Milano brings fashion, the image and transferring energy of New York City never sleeps. In addition, Hong Kong presents the concept of Asia's World City while Amsterdam is known as a freedom city. Other cities such as Washington, Tokyo, and Barcelona are known for employing power, modernity, and young culture. Brussels is increasingly becoming the centre of congresses, exhibitions, and conventions while Rome takes tourists to ancient times and Rio for entertainment (Järvisalo, 2012). Brands of these cities are simply identified with their history and features (Anholt, 2006). Globalization should be highlighted among the megatrends that affect on strategic decision making of cities' branding. Some initial tendencies in city branding processes (Braun, Kavaratzis, \& Zenker, 2013; Lucarelli \& Berg, 2011; Neirotti, et al., 2014; Zhang \& Zhao, 2009) consist of optimum utilization of internet and mobile technologies as well as using websites and academic evaluation with regard to concepts such as production, consumption and criticizing, implementation of sustainable projects, application of smart city management projects and principles, expanding global conventions, exhibitions, conferences, festivals to whole year in order to add the artistic image of city brand, considering the opinions of other partners apart from brands' images and brand positioning efforts with regard to employees, organizations, and visitors because traditional approaches require branding processes. Branding through sustainable activities of platform establishes via strategic partnerships and multi-disciplinary groups.

\section{Method}

In this study, both primary and secondary research data are used to gather information and the results of SWOT analysis of Izmir's city branding are presented in Table 1. It is a comprehensive literature review with brief and real life SWOT analysis examples on the topic of city branding and trends.

\section{SWOT Analysis of Izmir's Branding}

A SWOT analysis is a strategic planning and marketing management tool which a firm or a destination may use to identify its competitors' strong and weak points within a competition. It also takes into account the opportunities and threats that are happing in the operating field of the firms' or destination's environment including the industrial trends (İcelioglu, 2014; Tribe, 2010). As can be seen from Table 1, SWOT analysis focuses on firms' and destinations' present situations regarding their strengths and weaknesses at the time of presenting their opportunities and threats in the environment (Pırnar, 2011).

Table 1

SWOT Analysis of Izmir as a City Brand

\begin{tabular}{ll}
\hline Elements & Features \\
\hline Strengths & - Building numerous newly conventions and fair facilities \\
& - Local public and private investing on local culture attractions and increasing alternative thematic museums \\
& - Owning various attractions and appealing resources \\
& - Being popular in many different alternative tourism types like religious tourism, cruise, cittaslow, yacht tourism, health \\
& and thermal tourism, surfing, MICE, culture and agritourism. \\
& - Having high levels of awareness and positive consumer perception in the travel markets of Izmir \\
& - Existing many organizations such as convention bureaus and destination management companies working on \\
& positioning, brand image, and branding of Izmir
\end{tabular}




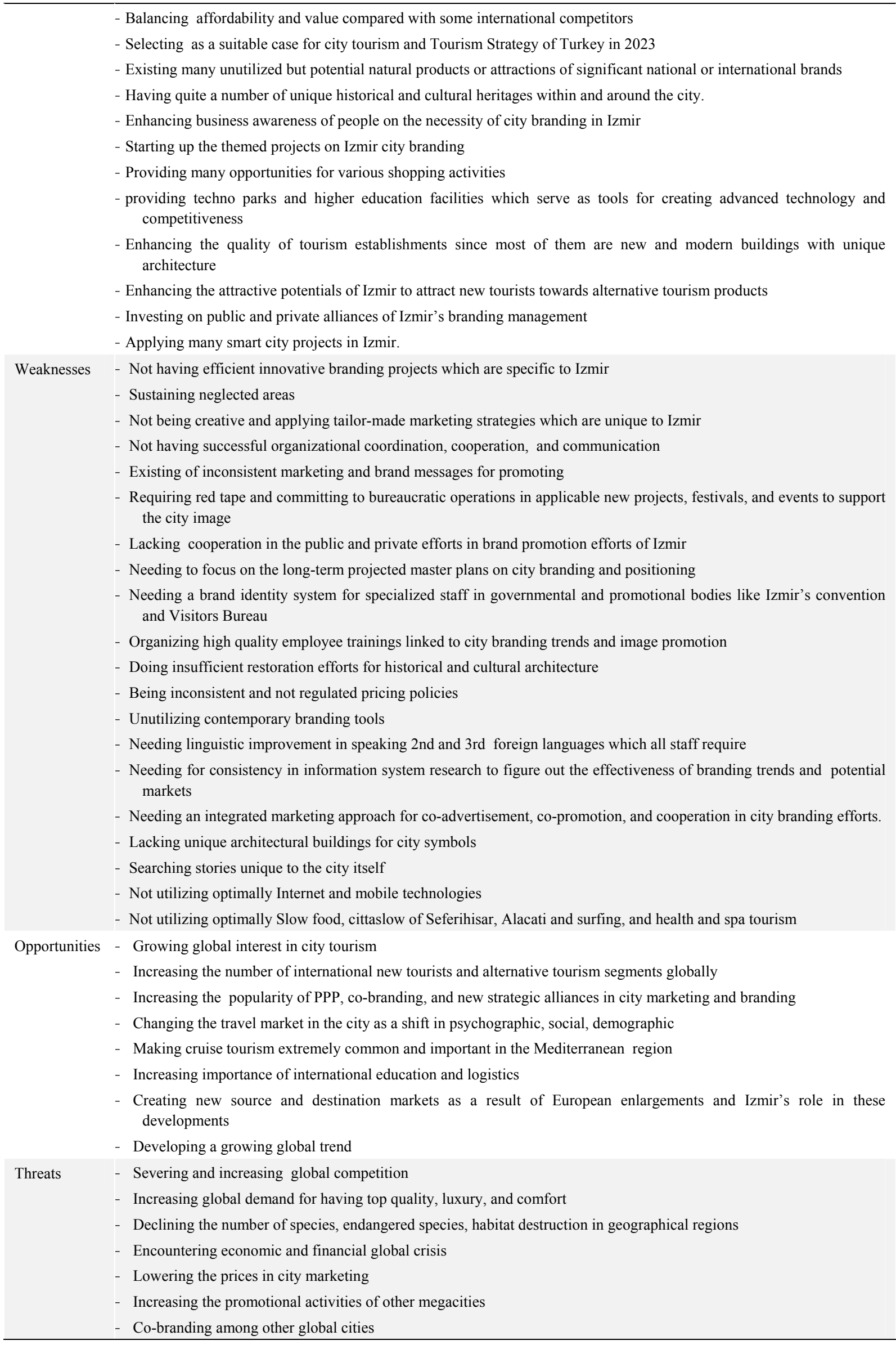




\section{Conclusion}

The results of the study indicated that there were some measures should be taken into account for improving the planning and management of Izmir city branding. These measures should be taken into consideration in compliance with other management practices for better sustainable applications. This paper produced practical suggestions for Izmir as a brand under two topics including branding and sustainability. If consideration is given to these suggestions as an outcome, it would enhance and strengthen Izmir's branding. Table 2 summarizes the obtained results. Despite the fact that the findings of this study claimed the effectiveness of city branding in organizations; there were some limitations in the implementation of the present study. First, the time span in this study was not enough to obtain comprehensive findings. Also, the reliance on secondary data analysis was considered as the second constraint of the study, comprehensive and more complex findings may be obtained through the usage of primary data.

Table 2

The Summary of the Obtained Results

\begin{tabular}{|c|c|}
\hline Policies & Practices \\
\hline \multirow{9}{*}{ Brand } & Izmir needs unique stories and special festivals for promotion \\
\hline & Izmir needs unique architectural buildings and art objects that could be regarded as city symbols. \\
\hline & $\begin{array}{l}\text { Izmir branding management should have a globalization perspective and should closely follow up the global city } \\
\text { branding trends. }\end{array}$ \\
\hline & $\begin{array}{l}\text { The topics such as destination management, destination marketing, city positioning suitable for changing global trends, } \\
\text { image building, and improvement are important for application. }\end{array}$ \\
\hline & Maintaining balance in statutory and voluntary approaches for city branding may be effective \\
\hline & $\begin{array}{l}\text { Slow food, cittaslow of Seferihisar, Alacati and surfing, health and spa tourism should optimally utilize in Izmir city } \\
\text { branding. }\end{array}$ \\
\hline & $\begin{array}{l}\text { Izmir city branding management strategies should emphasize brand loyalty applications, since they emphasize on } \\
\text { marketing communication and short-termed promotions. }\end{array}$ \\
\hline & $\begin{array}{l}\text { Training and certification of city promotion and branding specialized human resources working in related } \\
\text { organizations such as visitor bureaus and destination marketing organization's is needed. }\end{array}$ \\
\hline & $\begin{array}{l}\text { The familiarity of city attractions, favorability, and uniqueness are important contributors of place brand equity in } \\
\text { successful city branding; therefore, a plan should focus on all these three elements together. }\end{array}$ \\
\hline \multirow{9}{*}{ Sustainability } & $\begin{array}{l}\text { Ecological city management and urban sustainable development to achieve overall protection of representative } \\
\text { ecosystem in Izmir. }\end{array}$ \\
\hline & $\begin{array}{l}\text { Izmir needs strategic alliances and partnerships among public and private industries for cooperative branding and } \\
\text { smart city application projects. }\end{array}$ \\
\hline & $\begin{array}{l}\text { Total quality management and standardization applications in attractions, events, and festival management are } \\
\text { important. }\end{array}$ \\
\hline & $\begin{array}{l}\text { Making and working on zoning plans would reinforce on clustering and leading toward an effective development and } \\
\text { improvement in Izmir's important clusters. }\end{array}$ \\
\hline & $\begin{array}{l}\text { Involving local communities in sustainability through training and increasing the level of public participation may be } \\
\text { helpful. }\end{array}$ \\
\hline & Security and sustainability measures are key issues and need caution and attention. \\
\hline & $\begin{array}{l}\text { Sustainability programs and plans should be emphasized on ecologically friendly travel packages and programs and } \\
\text { should be added to tourism products. }\end{array}$ \\
\hline & $\begin{array}{l}\text { It is essential that the related staff has continuous training and periodical updates on issues about changing global city } \\
\text { management, sustainable city management, and smart city trends. }\end{array}$ \\
\hline & $\begin{array}{l}\text { Flexible plans of sustainable city destination marketing and management should be applied. Thus, reliable } \\
\text { measurement operations and periodic controls are considered also a requirement. }\end{array}$ \\
\hline
\end{tabular}




\section{References}

Aaker, D.A. (2001). Strategic market management. New York, NY: John Wiley \& Sons.

Anholt, S. (2006). The Anholt-GMI city brands index: How the world sees the world's cities. Place Branding \& Public Diplomacy, 2(1), 18-31.

Ashworth, G. J., \& Kavaratzis, M. J. (2009). Beyond the logo: Brand management for cities. Journal of Brand Management, $16(8), 520-531$.

Atesoglu, S. (2003). Monetary transmission-federal funds rate and prime rate. Journal of Post Keynesian Economics, 26(2), $357-364$.

Braun, E., Kavaratzis, M., \& Zenker, S. (2013). My city-my brand: The role of residents in place branding. Journal of Place Management \& Development, 6(1), 18-28.

Chan, C. S., Peters, M., \& Marafa, L. M. (2015). Public parks in city branding: Perceptions of visitors' vis-à-vis residents in Hong Kong. Urban Forestry \& Urban Greening, 14(4), 1157-1165.

Cifci, S., \& Cop, R. (2007). The terms of brand and brand management: An investigation about university students' jeans brand choices, finance. Political \& Economic Reviews, 44(512), 69- 88.

Demirbag Kaplan, M., Yurt, O., Guneri, B., \& Kurtulus, K. (2010). Branding places: Applying brand personality concept to cities. European Journal of Marketing, 44(9/10), 1286-1304.

Ekin, Y., \& Akbulut, O. (2013). Synopsis of Izmir regional plan and interpretations about tourism in Izmir (Special issue). Romanian Economic \& Business Review, 179-191.

Gregory, J. R. (2004). The best of branding: Best practices in corporate branding. New York: McGraw-Hill.

Hanna, S., \& Rowley, J. (2008). An analysis of terminology use in place branding. Place Branding \& Public Diplomacy, $4(1), 61-75$.

Järvisalo, S. (2012). How to build successful city brands? Case Munich, Berlin, and Hamburg (Unpublished master's thesis). Haaga-Heila University, Helsinki.

Jin, J., Gubbi, J., Marusic, S., \& Palaniswami, M. (2014). An information framework for creating a smart city through internet of things. Internet of Things Journal, IEEE, 1(2), 112-121.

Karabag, S. F., Yavuz, M. C., \& Berggren, C. (2011). The impact of festivals on city promotion: A comparative study of Turkish and Swedish festivals. Original Scientific Paper, 59(4), 447-464.

Kirdar, Y. (2003). Marka stratejilerinin olusturulmasi, Coca-Cola Ornegi. Review of Social, Economic, \& Business Studies, $3(4), 233-250$

Lucarelli, A., \& Berg, P. O. (2011). City branding: A state-of-the-art review of the research domain. Journal of Place Management \& Development, 4(1), 9-27.

Neirotti, P., De Marco, A., Cagliano, A. C., Mangano, G., \& Scorrano, F. (2014). Current trends in smart city initiatives: Some stylised facts. Cities, 38, 25-36.

Odabasi, Y., \& Oyman, M. (2004). Marka Kavrami ve Onemi. In G. Canan (Eds.), Pazarlama Illetisimi yonetimi icinde (pp. 359-380). Istanbul: Kapital Medya.

Oguztimur, S., \& Akturan, U. (2015). Synthesis of city branding literature (1988-2014) as a research domain. International Journal of Tourism Research, 18(4), 357-372.

Ozdemir, S., \& Karaca, Y. (2009). Kent markasi ve marka imajinin Olcumu: Afyonkarahisar kenti imaji uzerine bir arastirma. Dergisi, 6(2), 113-134.

Pirnar, I. (2014). Tourism education universities in Turkey: Comparison of different structures and related Effects on education quality. Procedia - Social \& Behavioral Sciences, 116, 5070-74.

Pirnar, I., (2011). Alternative tourism potential of Aegean region and implications for future. Paper presented at the Ninth Asia-Pacific CHRIE (APac-CHRIE) Conference on Hospitability and Tourism Education from a Vision to an Icon, Hong Kong, China.

Pirnar I., (2006). Ortak marka ve turizm sector nde uygulanmasi. Pazarlama ve İletisim Kulturu Dergisi, 5(18), 44-51.

Stigel, J., \& Frimann, S. (2006). City branding-all smoke, no fire? Nordicom Review, 27(2), 245-268.

Tek, M. (2009). Kamu Yatirimlarinda Turizmin Yeri, Turkiye Turizm Stratejisi 2023'de Marka Kentler Projesi: Elestirel Bir Degerlendirme. Anatolia: Turizm Arastirmalari Dergisi, 20(2), 169-184. 
Tribe, J., (2010). Strategy for tourism. Oxford: Goodfellow Publishers Limited.

Vanola, A. (2008). The image of the creative city: Some reflections on urban branding in Turin. Cities, 25(6), 370-382.

Zhang, L., \& Zhao, S. X. (2009). City branding and the Olympic effect: A case study of Beijing. Cities, 26(5), $245-254$. 